\title{
Primarily chronic and cerebrovascular course of Lyme neuroborreliosis: case reports and literature review
}

Marko Wilke, Helmut Eiffert, Hans-Jürgen Christen, Folker Hanefeld

\begin{abstract}
As part of an ongoing study aiming to define the clinical spectrum of neuroborreliosis in childhood, we have identified four patients with unusual clinical manifestations. Two patients suffered from a primarily chronic form of neuroborreliosis and displayed only non-specific symptoms. An 11 year old boy presented with long standing symptoms of severe weight loss and chronic headache, while the other patient had pre-existing mental and motor retardation and developed seizures and failure to thrive. Two further children who presented with acute hemiparesis as a result of cerebral ischaemic infarction had a cerebrovascular course of neuroborreliosis. One was a 15 year old girl; the other, a 5 year old boy, is to our knowledge the youngest patient described with this course of illness. Following adequate antibiotic treatment, all patients showed substantial improvement of their respective symptoms. Laboratory and magnetic resonance imaging findings as well as clinical course are discussed and the relevant literature is reviewed. (Arch Dis Child 2000;83:67-71)
\end{abstract}

Keywords: neuroborreliosis; chronic course; cerebrovascular accidents

Kinderklinik der Georg-AugustUniversität, Abteilung Kinderheilkunde, Schwerpunkt Neuropädiatrie, Robert-Koch-Straße 40, 37075 Göttingen, Germany

$M$ Wilke

H-J Christen

F Hanefeld

Zentrum Hygiene und Humangenetik der Georg-AugustUniversität, Abteilung Medizinische Mikrobiologie, Kreuzbergring 57, 37075 Göttingen, Germany H Eiffert

Correspondence to: Prof. Dr Hanefeld email: hanefield@ med.uni-goettingen.de

Accepted 14 January 2000
Lyme borreliosis is a tick borne multisystem disorder caused by an infection with the spirochete Borrelia burgdorferi. Following its discovery in 1982, a wide range of clinical manifestations have been attributed to this disease, including affections of skin, joints, heart, eyes, and the cardiovascular and nervous system. ${ }^{12}$ The term neuroborreliosis has been introduced $^{3}$ to denote the involvement of the central or peripheral nervous system, which occurs in $10-15 \%$ of affected adults. ${ }^{4}$

Neurological manifestations are even more common in children ${ }^{56}$ and comprise cranial neuritis (especially facial palsy) and aseptic meningitis in the majority of patients. ${ }^{57}$ During an ongoing study aiming to clarify the clinical spectrum of neuroborreliosis in childhood, we have seen two patients presenting with nonspecific symptoms who had a primarily chronic form of neuroborreliosis. Two further patients were seen experiencing a peculiar yet similar course of their respective illnesses. We believe this to be a manifestation of cerebrovascular neuroborreliosis.

\section{Case reports}

CASE 1

This 11 year old boy had been healthy until he developed chronic headache and learning difficulties, recurrent episodes of arthralgia in both hips, and severe weight loss. Two months previously, he had been to a scout camp in the Bavarian forest but recalled neither a tick bite nor skin changes. He was seen by an orthopaedic surgeon who excluded cervical spine pathology; cranial computed tomography (CT) and magnetic resonance imaging (MRI) scans revealed no abnormalities. Psychosomatic disease was suspected and he was referred to us four months after the onset of symptoms for further diagnostic evaluation.

On admission he was neurologically asymptomatic, and routine laboratory investigations showed no abnormalities. Table 1 summarises further investigations. Serology for B burgdorferi was positive for IgG and IgM antibodies in both CSF and serum by enzyme immunoassay (EIA), confirmed by Western blot. The specific $\mathrm{CSF} /$ serum antibody index was 3.8 for $\mathrm{IgG}$ and 1.9 for $\operatorname{IgM}$ antibodies (normal <1.5), implying intrathecal production. CSF showed notable inflammatory changes with a raised cell count $\left(325 \times 10^{6} / 1\right)$, highly increased protein $(3.145 \mathrm{~g} / \mathrm{l})$, and a substantially disturbed blood-brain barrier indicated by a CSF:serum albumin ratio of $41.9 \times 10^{-3}$ (normal $\left.<5 \times 10^{-3}\right)$. Correlation of the CSF immunoglobulins with serum values revealed global intrathecal production of IgG and IgM. CSF lactate was increased to $3.4 \mathrm{mmol} / 1$, and identical oligoclonal IgG bands were detected in serum and CSF. Treatment with intravenous cefotaxime $(60 \mathrm{mg} / \mathrm{kg} /$ day $)$ for 14 days was initiated. Under treatment, he gained $4 \mathrm{~kg}$ of body weight and was discharged in good clinical condition.

No further episodes of severe headache or joint pain had occurred on follow up six months later. Serology for B burgdorferi was still positive for both IgG and IgM antibodies.

\section{CASE 2}

This boy developed mild mental and motor retardation and seizures after he had suffered from severe encephalopathy during a stay in South Africa at the age of 9 months. No infectious agent was isolated. At the age of 17 years, he experienced increasing motor disturbances and repeated seizures. On admission he was in good condition but small for his age (height $149 \mathrm{~cm},<3 \mathrm{rd}$ centile). Muscle tone was mildly increased, plantar reflexes were downgoing on both sides, and ataxia and dysarthria were 
Table 1 Clinical and laboratory data

\begin{tabular}{|c|c|c|c|c|}
\hline & Patient 1 & Patient 2 & Patient 3 & Patient 4 \\
\hline $\begin{array}{l}\text { Normal } \\
\text { results }\end{array}$ & $\begin{array}{l}\text { BCG skin test, CMV, EBV, } \\
\text { clotting factors, ACTH, } \\
\text { ammonia, bilirubin, cortisone, } \\
\text { ferritine, liver and pancreatic } \\
\text { enzymes, thyroid hormones, } \\
\text { urea, AFP, CEA, } \beta \text {-HCG, } \\
\beta \text { carotene }\end{array}$ & $\begin{array}{l}\text { Coxsackie virus B1-B5, cysticercosis, } \\
\text { HIV, listeriosis, rubella, syphilis, } \\
\text { toxoplasmosis, trypanosomiasis, } \\
\text { histology of muscle and skin specimen }\end{array}$ & $\begin{array}{l}\mathrm{CMV} \text {, listeriosis, measles, } \\
\text { mycoplasma, syphilis, TBE, } \\
\text { toxoplasmosis, VZV, echo- and } \\
\text { electrocardiography, blood pressure, } \\
\text { clotting factors, immunoglobulins, } \\
\text { complement factors, autoantibodies }\end{array}$ & $\begin{array}{l}\text { Adenovirus, enterovirus, HSV, } \\
\text { influenza, measles, parainfluenza, } \\
\text { rubella, toxoplasmosis, } \\
\text { AFP/CEA/ } \beta-H C G \text { in CSF clotting } \\
\text { factors, protein C\&S, VLCFA, } \\
\text { phytanic acid, echo- and } \\
\text { electrocardiography, blood pressure, } \\
\text { neurophysiology, autoantibodies }\end{array}$ \\
\hline
\end{tabular}

observed. He showed no physical signs of puberty and had not gained height or weight during the previous 14 months. Cranial CT and MRI scans showed periventricular demyelination. Lumbar puncture was performed for suspected metabolic encephalopathy and showed inflammatory changes with pleocytosis $\left(99 \times 10^{6} / 1\right)$, increased protein $(2.036 \mathrm{~g} / \mathrm{l})$, and notable intrathecal production of antibodies involving IgG, IgA, and IgM. Oligoclonal IgG was detected in CSF, lactate was increased ( $5.6 \mathrm{mmol} / \mathrm{l})$, and glucose was low $(1 \mathrm{mmol} / \mathrm{l})$. CSF serology showed intrathecal production of IgM and IgG antibodies to B burgdorferi. Increased antibody indices (IgG class) for varicella zoster virus (VZV), herpes simplex virus (HSV), rubella, and measles were also present. Antibiotic therapy was initiated (penicillin G $160000 \mathrm{IU} / \mathrm{kg} /$ day for 10 days), leading to a fall in CSF cell count while protein and lactate $(5.5 \mathrm{mmol} / \mathrm{l})$ were unchanged. The patient tolerated therapy well and was discharged in good condition.

Repeat lumbar puncture seven weeks later showed a persistently increased cell count but protein and CSF antibody production had fallen substantially. Anti-B burgdorferi IgG antibodies were still detectable. Lactate had decreased to $4.7 \mathrm{mmol} / \mathrm{l}$. A second course of antibiotic treatment with intravenous ceftriaxone $(50 \mathrm{mg} / \mathrm{kg} /$ day for 12 days) was well tolerated.

Nine months later, CSF cell count was $7 \times 10^{6} / 1$, lactate was normal $(1.5 \mathrm{mmol} / \mathrm{l})$, and protein mildly increased. Specific antibodies against $B$ burgdorferi (IgG and $\operatorname{IgM}$ ) were not detected in serum or CSF. Repeat MRI scan 18

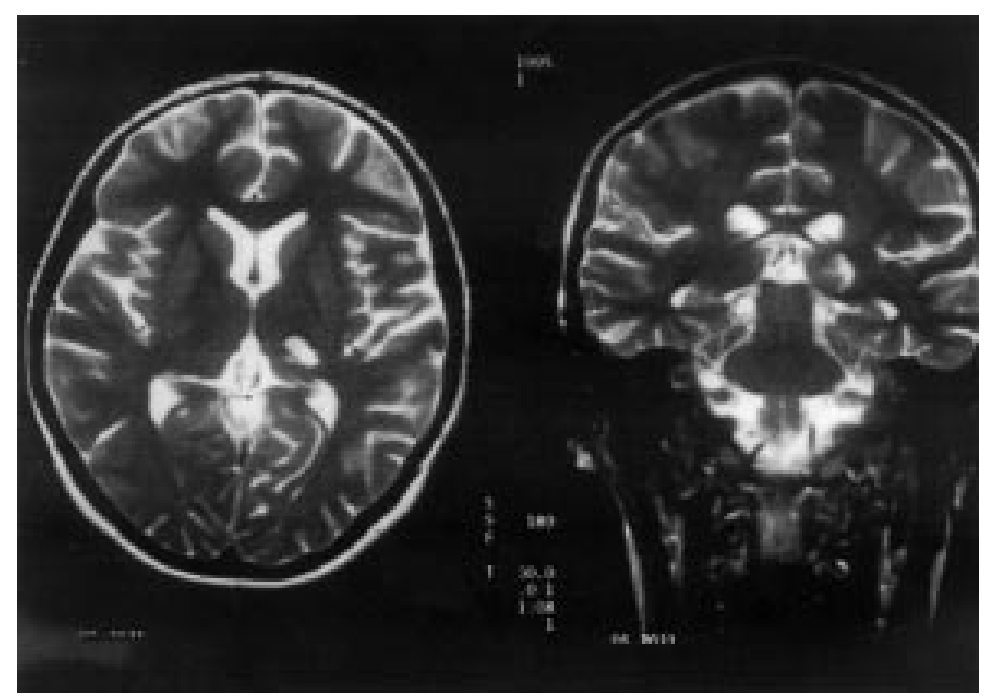

Figure 1 Cranial MRI of patient 3. months after diagnosis showed substantial remission of the periventricular changes. A few months after therapy, the patient had gained weight and height considerably, and puberty had begun. After three more seizures and a switch to carbamazepine, no further seizures occurred. The patient was subsequently entered into a special training programme.

CASE 3

This 15 year old girl developed an acute right sided hemiparesis following a tick bite six weeks previously. There was a five week history of abdominal discomfort, vomiting, headache, and slight mental slowing. Initial MRI scan showed a lesion in the left sided basal ganglia and the posterior internal capsule (fig 1); she was admitted to hospital for suspected multiple sclerosis and treated with intravenous prednisone $(0.75 \mathrm{mg} / \mathrm{kg} /$ day $)$.

On admission, she showed a right sided hemiparesis with bradydiadochokinesis and minimal right sided ataxia. She had prominent and indistinct retinal papillae on both sides, consistent with papillitis. CSF showed an increased cell count $\left(64 \times 10^{6} / 1\right)$ and protein content $(1.132 \mathrm{~g} / \mathrm{l})$. A highly increased antibody index for $B$ burgdorferi specific antibodies of both the IgM (4.2) and IgG class (14.7) as well as a mildly increased HSV antibody index were detected.

Under treatment with penicillin G (225000 $\mathrm{IU} / \mathrm{kg} /$ day for 14 days), followed by intravenous ceftriaxone $(35 \mathrm{mg} / \mathrm{kg} /$ day for 14 days) her neurological deficits showed a steady clinical improvement. Lumbar puncture was repeated 17 days after admission and showed a decrease in CSF cell count and protein. The increased specific HSV antibody index had normalised. On discharge she still displayed mild right sided weakness.

Eight weeks later, she had completely recovered. CSF showed normal cell count and glucose while protein was still mildly increased. $B$ burgdorferi specific antibodies could not be detected in CSF or serum. Cerebral MRI scan five months after the onset of symptoms showed two residual lesions. On clinical examination, she displayed no neurological deficits.

CASE 4

This 5 year old boy developed an acute left sided hemiparesis with disturbed speech. He remembered being bitten by a tick six weeks before and had suffered from chicken pox six months prior to this episode, but had been otherwise healthy.

On examination, he showed no neurological abnormalities apart from a minimal left sided 


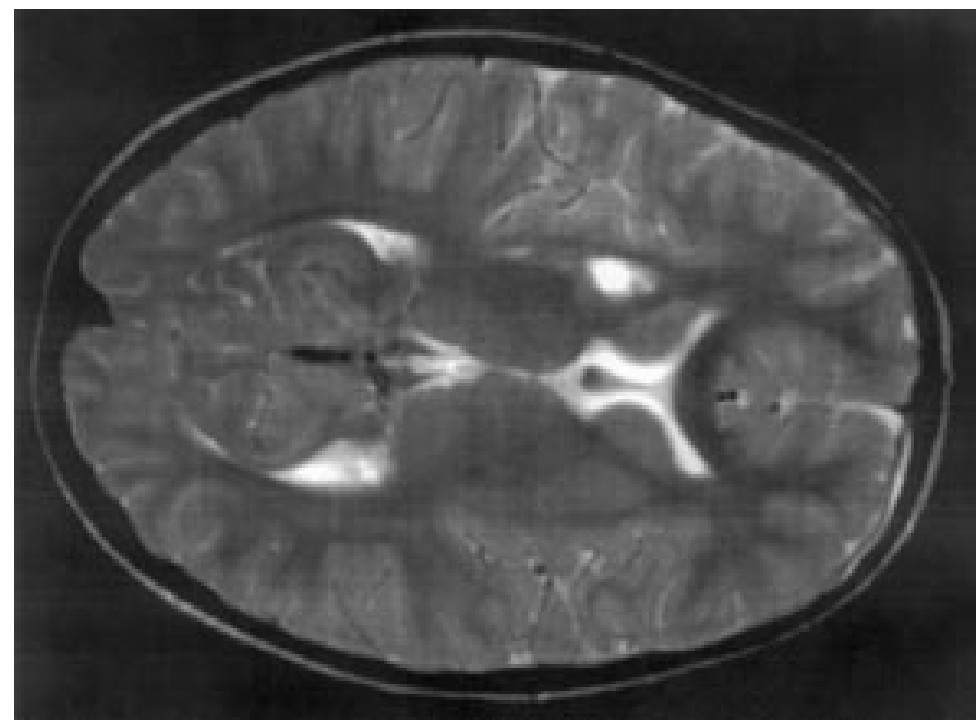

Figure 2 Cranial MRI of patient 4.

facial weakness. During the following days, five further episodes of transient hemiparesis with blurred speech occurred, each lasting about 5-10 minutes. In between times he was well and neurologically asymptomatic. B burgdorferi specific antibodies of both IgG (Western blot) and IgM class (Western blot and EIA) were detected in serum. Lumbar puncture was performed after two weeks, showing a borderline cell count $\left(5 \times 10^{6} / 1\right)$, increased protein $(0.67 \mathrm{~g} / 1)$, and normal glucose. Cranial MRI scan 10 days after admission showed infarction in the right sided basal ganglia (fig 2). Treatment with acetylsalicylic acid ( $5 \mathrm{mg} / \mathrm{kg} /$ day) and prednisone $(2 \mathrm{mg} / \mathrm{kg} /$ day $)$ was begun before he was transferred to our unit for further investigation.

On admission he showed no neurological abnormalities apart from an upgoing plantar reflex on the left side. Further investigations were normal (table 1). Lumbar puncture showed a normal CSF protein $(0.26 \mathrm{~g} / \mathrm{l})$, again with a borderline cell count $\left(5 \times 10^{6} / 1\right)$. Specific antibodies against $B$ burgdorferi were not detected in CSF (EIA) but an increased antibody index for VZV (IgG class) was present. IgM antibodies against VZV were not detected in serum or CSF. Repeat MRI scan confirmed the defect in the basal ganglia, and MR angiography showed a slight narrowing in the right sided medial cerebral artery. Antibiotic therapy with ceftriaxone $(100 \mathrm{mg} / \mathrm{kg} /$ day $)$ was given while prednisone dose was reduced.

No further episodes had occurred on follow up five weeks later, and on examination he was completely normal. On MRI scan, only a residual lesion could be seen. Lumbar puncture showed a normal cell count $\left(2 \times 10^{6} / 1\right)$ and normal protein $(0.291 \mathrm{~g} / \mathrm{l})$, with a persistently increased antibody index for VZV. Using EIA, $B$ burgdorferi specific antibodies were undetectable in blood and CSF.

\section{Discussion}

CLINICAL COURSE AND LABORATORY DATA

Our four patients represent two different courses of illness. The first two patients presented with a primarily chronic course: unspecific malaise with headache and severe weight loss dominated the clinical picture in the first case, whereas a very complex chronic symptomatology with mental and physical retardation was present in the second. Patients 3 and 4 developed acute and (in patient 4) recurrent hemiparesis caused by cerebrovascular neuroborreliosis.

Presentation with a chief complaint of considerable weight loss as in patient 1 has been reported in borreliosis, ${ }^{8}$ although we found only one case report in the German language literature presenting as "pseudoanorexia". ${ }^{9}$ As a wide variety of neuropsychiatric disturbances have been linked to Lyme disease, ${ }^{810}$ we think that it is important to point out the possible connection between infection with "the new great imitator" B burgdorferi and these disorders. ${ }^{8}$ Considering the association of neuroborreliosis with vasculitis, ${ }^{11-13}$ the close correlation between cerebral blood flow and neural activity, ${ }^{14}$ and the recent findings of cerebral hypoperfusion in late Lyme borreliosis ${ }^{10}$ suggest there might be a pathophysiological link between perfusion deficits and neuropsychiatric symptoms in neuroborreliosis as suggested before in other conditions. ${ }^{14}{ }^{15}$ It is also interesting to note that this patient (who had no focal neurological deficits) had the most notable inflammatory CSF changes we have seen in the past four years.

In the second patient, the onset of symptoms and the clinical course of disease are most remarkable and unusual: after a long standing unclassified stable encephalopathy, cerebral seizures recurred at the age of 17 years. Cranial MRI scans suggested a metabolic disorder. When the diagnosis of chronic neuroborreliosis was finally established and the appropriate treatment given, not only did his neurological and mental status improve but he also gained height considerably and puberty started. This has never previously been reported in neuroborreliosis. The substantial white matter changes in this patient considerably improved following antibiotic treatment, suggesting either a parenchymal or a vascular inflammation directly related to the presence of $B$ burgdorferi. White matter changes suggestive of leukencephalopathy have been reported in late Lyme borreliosis, ${ }^{6} 1617$ showing reversibility in some cases. ${ }^{18}$ Furthermore, in a recent study of patients with suspected late Lyme encephalopathy, perfusion deficits were found, especially in central white matter and the basal ganglia region, which partly resolved following antimicrobial therapy. ${ }^{10}$ These findings might also hint at vasculitis as an important pathological mechanism in neuroborreliosis.

The CSF lactate concentrations in this patient are remarkable: initial lumbar puncture showed an increased lactate $(5.6 \mathrm{mmol} / \mathrm{l})$ as in the other patient with a chronic course of illness (patient $1,3.4 \mathrm{mmol} / \mathrm{l})$. In contrast, our two patients with an acute illness only had borderline lactate concentrations (patient 3, $2.2 \mathrm{mmol} / 1$; patient 4, $2.1 \mathrm{mmol} / \mathrm{l})$. To our knowledge this association of (chronic) neuroborreliosis and high CSF lactate has not been reported 
previously. As clinical presentation in chronic neuroborreliosis may resemble a chronic multisystem disorder, CSF lactate may therefore be misleading as an indicator of a metabolic (for example, mitochondrial) disease. ${ }^{19}$

Our third patient presented with acute hemiparesis, paraesthesia, and papillitis; MRI scan showed ischaemic infarction involving the basal ganglia (fig 1), and the diagnosis of acute, cerebrovascular neuroborreliosis was made. Both of her manifestations (cerebral ischaemic infarction $^{18} 20_{21}$ and papillitis ${ }^{22}$ ) have been described in childhood neuroborreliosis.

The last patient presented with six episodes of transient, acute neurological symptoms. MRI scan showed ischaemic lesions in the basal ganglia (fig 2). Clinical as well as radiological findings were in line with previously described manifestations of Lyme neuroborreliosis, ${ }^{182021}$ as is the history of a tick bite six weeks prior to developing neurological symptoms. ${ }^{5}$ As our patient had suffered from chicken pox six months previously, and an increased antibody index for varicella zoster was found, differential diagnosis included post-varicella cerebral vasculitis. ${ }^{23} 24$ However, the described latency period before developing neurological symptoms after chicken pox ranges from 11 days to 12 weeks after the primary illness, ${ }^{23}{ }^{24}$ whereas in our patient it would have been six months. Moreover, the pattern of lesions in our patient, with the involvement of basal ganglia, internal capsule, and thalamus, is compatible with previously reported vascular incidents in neuroborreliosis. ${ }^{17}{ }^{20}$ In contrast, VZV infection tends to induce large vessel vasculitis. ${ }^{23}{ }^{25}$ Furthermore, an increased antibody index alone (reflecting intrathecal production of antibodies compared with serum ${ }^{26}{ }^{27}$ ) may not serve as a marker of active infection ${ }^{26}$; this has been observed previously ${ }^{28}$ for some time after VZV infection, although the relevance of this finding to VZV angiopathy is not known. ${ }^{29}$ It may represent an "immunological scar", ${ }^{17}$ a cross reaction with $\mathrm{HSV},{ }^{28}$ or a sign of non-specific $\mathrm{B}$ cell activation as proposed in multiple sclerosis. ${ }^{30} \mathrm{~A}$ polyclonal production of antibodies has also been described in patients with late Lyme neuroborreliosis, ${ }^{27}{ }^{31}$ and is known to give false results in the calculation of antibody indices. ${ }^{30}$

We acknowledge that laboratory data in this case are somewhat equivocal. However, taking into account the serological evidence and other laboratory and clinical data, we made the diagnosis of cerebrovascular neuroborreliosis. The patient responded well to antibiotic treatment. Despite the uncertainties in this case we have reported it, as it illustrates the difficulties in diagnosing neuroborreliosis in the presence of an atypical clinical pattern. In this context, even the complete absence of specific antibodies has been observed: in a girl diagnosed as having focal vasculitis through CNS biopsy, the presence of $B$ burgdorferi in CSF was confirmed by polymerase chain reaction. No specific antibodies were detectable. ${ }^{18}$ In three other children, ${ }^{7}$ B burgdorferi could be cultured from CSF in the absence of specific antibodies in CSF or blood. Possible reasons for this might be: (1) restricted access caused by the immunoprivileged status of the central nervous system $^{13}$ in focal neurological manifestations; (2) local production of antibodies, which in some cases might not emerge into the surrounding $\operatorname{CSF}^{1618}$; (3) a shift in the immune response from humoral to cellular components ${ }^{13}{ }^{16}$; or (4) antibodies might not yet be detectable in the early course of illness ("diagnostic gap")..$^{5}$

CHRONIC NEUROBORRELIOSIS IN CHILDHOOD

Chronic neuroborreliosis is considered a very rare finding in children. ${ }^{2}{ }^{6}$ As one neurological manifestation of "late Lyme disease", it must be distinguished from "late Lyme encephalopathy", which is characterised rather by psychopathological disturbances in the absence of inflammatory changes in CSF and clinically resembles chronic fatigue syndrome. ${ }^{32}$ Nondifferentiation between these two clinical entities might account for some of the heterogeneous clinical as well as laboratory findings in "late Lyme disease". ${ }^{32}$

While chronic neuroborreliosis is believed to be an active and ongoing infection with regularly associated CSF changes, ${ }^{32}$ the aetiology and indeed the very existence of late Lyme encephalopathy are not so clear. ${ }^{17}$ Some authors discuss an immunological process in the absence of a continuing infection, ${ }^{18}{ }^{32}$ a toxic metabolic encephalopathy, ${ }^{16}$ an effect of systemic liberation of neuromodulators, ${ }^{32}$ or consider the findings to be largely caused by residual symptoms ${ }^{17}$ or a coincidental occurrence of two separate illnesses. ${ }^{33}$ Sigal $^{34}$ proposes seven possible pathogenetic mechanisms for symptoms that may lead to the diagnosis of "chronic Lyme disease", only one of which involves active and ongoing infection.

Here we report two children whose findings are consistent with the diagnostic criteria set up for chronic neuroborreliosis. ${ }^{14} 1732$ Presentation consisted of slight neuropsychiatric changes and weight loss in one and of a complex clinical picture, including growth arrest and developmental delay, in the other. In line with other investigators, ${ }^{17}$ we observed an excellent clinical and CSF response to antibiotic treatment which strongly suggests active infection. ${ }^{32}$

Despite the clear peak incidence of neuroborreliosis during the summer months, ${ }^{15-7}$ both of our patients with chronic neuroborreliosis presented during wintertime. As we have not seen any further patients with neuroborreliosis from November to April during the past four years, it seems important to remember that presentation is possible throughout the year.

CEREBROVASCULAR NEUROBORRELIOSIS

Two of our patients (patients 3 and 4) developed acute and recurrent hemiparesis, respectively. Cranial MRI scans showed ischaemic lesions in the vascular territory of the middle cerebral artery. ${ }^{35}$ Serology confirmed infection with $B$ burgdorferi and symptoms responded well to antibiotic therapy. Therefore we believe that the vascular accidents in these 
patients are a manifestation of what we termed a "cerebrovascular course" of neuroborreliosis.

Vasculitis has for a long time been postulated as the mechanism of nervous system injury in $B$ burgdorferi infection, ${ }^{11}{ }^{12}$ and case reports of several patients have been published. ${ }^{31317}$ An immunological process leading to the vascular changes has been suggested, ${ }^{4} 111218$ supported by the fact that peripheral neuropathy in Lyme disease occurs on the basis of small vessel vasculitis but in the absence of detectable borreliae. ${ }^{12} 33$ Cross reacting antibodies and antibodies directed against neuronal proteins $^{3133}$ also point in this direction. It is interesting to note that both patients with a cerebrovascular course of neuroborreliosis manifested within seven weeks and were referred to us from the same region. Since different genospecies of borrelia have been associated with distinct clinical symptoms, ${ }^{35}$ there could be a common determinant in both cases (in microorganism or host) leading to similar clinical manifestations.

With regard to the number of adult cases mentioned above and to the fact that neurological complications are more common in childhood borreliosis, ${ }^{56}$ it seems remarkable that only three case reports of hemiparesis or stroke like episodes in childhood borreliosis have been published. ${ }^{182021}$ The youngest patients to date were a 13 year old boy ${ }^{21}$ and an 11 year old girl, ${ }^{18}$ with a further occurrence in a 16 year old boy. ${ }^{20}$ As this complication has only recently been recognised as part of the clinical spectrum of childhood neuroborreliosis, it might still go undiagnosed in some patients. We therefore believe that, in children with cerebrovascular accidents, special attention should be paid to clinical, serological, and CSF findings compatible with an infection with $B$ burgdorferi which can be treated successfully. ${ }^{25}$

We would like to thank Prof. Reiber for performing neurochemical analysis. We are indebted to Dr Ozminski, Kreiskrankenhaus Blankenburg, and Dr Neumann, Klinikum Quedlinburg, for kind referral of two patients. We also thank $\mathrm{Mr} M$ Cohen for reviewing the manuscript. This study has been financed by a grant from the Bundesministerium für Bildung, Wissenschaft, Forschung und Technologie, Grant No. $01 \mathrm{~K}$ $9507 / 7$. Responsibility for the content of this publication lies solely with the authors.

1 Centers for Disease Control and Prevention. Case definitions-Lyme disease. Morb Mortal Wkly Rep Surveil Summ 1997;46:961

2 Stanek G, O'Connell S, Cimmino M, et al. European Union concerted action on risk assessment in Lyme borreliosis: clinical case definitions for Lyme borreliosis. Wien Klin Wochenschr 1996;108:741-7.

3 Veenendaal-Hilbers JA, Perquin WVM, Hoogland $\mathrm{PH}$, Doornbos L. Basal meningo-vasculitis and occlusion of the basilar artery in two cases of Borrelia burgdorferi infection. Neurology 1988;38:1317-19.

4 Garcia-Monco JC, Benach JL. Lyme neuroborreliosis. Ann Neurol 1995;37:691-702.

5 Christen HJ, Hanefeld F, Eiffert H, Thomsson R. EpidemiChristen HJ, Hanefeld F, Eiffert H, Thomsson R. Epidemi-
ology and clinical manifestations of Lyme borreliosis in childhood-a prospective multicentre study with special regard to neuroborreliosis. Acta Paediatr Suppl 1993;386:1 76.

6 Hansen K, Lebech AM. The clinical and epidemiological profile of Lyme neuroborreliosis in Denmark 1985-1990. Brain 1992;115:399-423.

7 Millner M. Die Lyme-Borreliose im Kindesalter. Padiatr Padol 1992;27:A81-2.
8 Dupuis MJM. Les multiples manifestations neurologiques des infections á Borrélia burgdorferi. Rev Neurol (Paris) 1988;144:65-775.

9 Stahl M, Fressle R, Wilske B. Lyme-Neuroborreliose unter dem Bild einer Anorexia nervosa. Munch Med Wochenschr 1990;132:615-20.

10 Logigian EL, Johnson KA, Kijewski MF, et al. Reversible cerebral hypoperfusion in Lyme encephalopathy. Neurology 1997;49:1661-70.

11 Garcia-Monco JC. Pathomechanismen der Neuroborreliose. Wien Med Wochenschr 1995;145:174-7.

12 Meier C, Grehl H. Vaskulitische Neuropathie bei GarinBujadoux-Bannwarth-Syndrom. Dtsch Med Wochenschr 1988;113:135-8.

13 Oksi J, Kalimo H, Marttila RJ, Marjamäki M, Sonninen P, Nikoskelainen J, Viljanen MK. Intracranial aneurysms in three patients with disseminated Lyme borreliosis: cause or chance association? f Neurol Neurosurg Psychiatry 1998;64: 636-42.

14 Nozoe S, Naruo T, Nakabeppu Y, Soejima Y, Nakajo M, Tanaka $\mathrm{H}$. Changes in regional cerebral blood flow in patients with anorexia nervosa detected through single photon emission tomography imaging. Biol Psychiatry photon emission

15 Moriarty J, Costa DC, Schmitz B, Trimble MR, Ell PJ, Robertson MM. Brain perfusion abnormalities in Gilles de la Tourette's syndrome. Br F Psychiatry 1995;167:249-54.

16 Halperin JJ, Volkman DJ, Wu P. Central nervous system abnormalities in Lyme neuroborreliosis. Neurology 1991; 41:1571-82.

17 Krüger H, Heim E, Schuknecht B, Scholz S. Acute and chronic neuroborreliosis with and without CNS involvement: a clinical, MRI, and HLA study of 27 cases. $\mathcal{F}$ Neurol 1991;238:271-80.

18 Oksi J, Kalimo H, Marttila RJ, Marjamäki M, Sonninen P, Nikoskelainen J, Viljanen MK. Inflammatory brain changes in Lyme borreliosis-a report on three patient and review of the literature. Brain 1996;119:2143-54

19 Hoffmann GF, Surtees RAH, Wevers RA. Cerebrospinal fluid investigations for neurometabolic disorders. Neuropediatrics 1998;29:59-71.

20 Lock G, Berger G, Gröbe H. Neuroborreliose: Progressive Encephalomyelitis mit cerebraler Vaskulitis. Monatsschr Kinderheilkd 1989;137:101-4.

21 Mourin S, Bonnier C, Bigaignon G, Lyon G. Épilepsie révélatrice d'une Neuroborréliose. Rev Neurol (Paris) 1993;149:489-91.

22 Pradella SP, Krause A, Müller A. Akute Borrelien Infektion: unilaterale Papillitis als isolierte klinische Manifestation. Ophthalmologe 1997;94:591-4.

23 Kamholz J, Tremblay G. Chickenpox with delayed contralateral hemiparesis caused by cerebral angiitis. Ann Neurol 1985;18:358-60

24 Caekebeke JFV, Peters ACB, Vandvik B, Brouwer OF, de Bakker HM. Cerebral vasculopathy associated with pri-
mary varicella infection. Arch Neurol 1990;47:1033-5.

25 Kleinschmidt-DeMasters BK, Amlie-Lefond C, Gilden DH. The patterns of varicella zoster virus encephalitis. Hum Pathol 1996;27:927-38.

26 Reiber H, Lange P. Quantification of virus-specific antibodies in cerebrospinal fluid and serum: sensitive and specific detection of antibody synthesis in brain. Clin Chem 1991;37:1153-60.

27 Nölker GC. Borrelien-Antikörper-Nachweis der IgG- und IgM-Klasse in Liquor und Serum: die sensitive Diagnose der Neuroborreliose mit dem Antikörper-Index. Doctoral thesis, Medical Faculty, Georg-August-University Göttingen, 1991 .

28 Vandvik B, Sköldenberg B, Forsgren M, Stiernstedt G, Jeansson S, Norrby E. Long-term persistence of intrathecal virus-specific antibody responses after herpes simplex encephalitis. F Neurol 1985;231:307-12.

29 Grau AJ, Buggle F, Hacke W. Infektionskrankheiten als Ursache und Risikofaktor für zerebrovaskuläre Ischämien. Nervenarzt 1996;67:639-49.

30 Luxton RW, Thompson EJ. Affinity distributions of antigenspecific IgG in patients with multiple sclerosis and in patients with viral encephalitis. $f$ Immunol Methods 1990;131:277-82.

31 Kaiser R. Intrathecal immune response in patients with neuroborreliosis: specificity of antibodies for neuronal proteins. F Neurol 1995;242:319-25.

32 Schmutzhard E, Pfausler B, Gasse T, Hittmar-Delazer M, Benke T. Verlaufsformen und Folgezustände bei chronischer Neuroborreliose. Wien Med Wochenschr 1995;27: 183-6.

33 Sigal LH. Lyme disease: a review of aspects of its immunology and immunopathogenesis. Annu Rev Immunol 1997;15: 63-92.

34 Sigal LH. Persisting complaints attributed to chronic Lyme disease: possible mechanisms and implications for management. Am f Med 1994;96:365-74

35 Brower MC, Rollins N, Roach ES. Basal ganglia and thalamic infarction in children. Cause and clinical feature. Arch Neurol 1996;53:1252-6. 